\title{
SPONTANEOUS MEDICINAL PLANTS: UTI SED NON ABUTI! A CASE STUDY - MUREŞ COUNTY
}

\author{
Vasile CRISTEA ${ }^{1,2}$, Simona MIH $\breve{A L E S C U^{3}, \text { Eliana SEVIANU }}{ }^{4}$ \\ ${ }^{1}$ Babeş-Bolyai University, Department of Taxonomy and Ecology, \\ Republicii str., 42, RO-400015, Cluj-Napoca, Romania \\ ${ }^{2}$ Nature Monuments Commission, Romanian Academy, Calea Victoriei, 125, RO-010071, Bucharest, România \\ ${ }^{\mathbf{3}}$ Biology Institute, Bucharest, Romanian Academy, Spl. Independenţei, 296, RO-060031, Bucharest, România \\ ${ }^{4}$ Babeş-Bolyai University, Faculty of Environmental Science, \\ 30 Fântânele str., RO-400294, Cluj-Napoca, România \\ e-mail: vasile.cristea@ubbcluj.ro
}

\begin{abstract}
Romania's natural resources are currently subjected to aggressive and barely controlled exploitation. These resources include medicinal plants from the spontaneous flora, which are much more in demand and appreciated on the foreign market than those derived from cultivation. Having information available regarding commercial societies (S.C.) and physical persons (P.P.) whose sphere of activity also comprises this resource, we wish to argue, taking Mureș county and the year 2017 as an example, the need for moderation in using all renewable as well as non-renewable resources. The requested quantities involved $109 \mathrm{spp}$. of spontaneous medicinal plants and amounted to 7,706 $\mathbf{t}$ (of which only $8 \mathrm{t}$ required by P.P.), while the institutions authorized to perform adequate evaluation (AE) studies proposed 4,529 $\mathbf{t}$ and the NMC approved only 3,926 t. Certainly, S.C.s in particular are dissatisfied with the approved quantities and have recourse to a wide range of "strategies". Even if in Mureş county pressure is not as high as in other counties in Transylvania, we believe that all organizations concerned with environmental conservation and protection should fight for the sustainable use (uti sed non abuti) of this important resource, which in most cases is subjected to other pressures in addition to those related to harvesting and export as raw material.
\end{abstract}

Key words: medicinal plants, Mureş county, sustainable conservation

\section{Introduction}

The aim of our paper is to argue, with concrete data and taking Mureș county as an example, the need for moderation in utilising all renewable as well as non-renewable resources. This moderation is also required because "Using the planet's natural resources is not an exclusive privilege of the current generation..." [2, p. 213], and their management "... has a pronounced global and at the same time national characteristic..." [idem, p. 214].

In general, Romania's natural resources are currently subjected to aggressive and barely controlled exploitation, for reason that are varied and difficult to understand! Considered as "strategic reserves", the work "Romania's development strategy for the next 20 years" (published by the Romanian Academy, 2015) emphasizes: "Any medium and long-term strategy for the sustainable development of Romania should start from the conservation and careful use of the national natural heritage" [13, p. 38]. This heritage includes medicinal plants from the spontaneous flora, which are much more sought after and appreciated on the foreign market than those derived from cultivation regimes specially created for this category of plant. 
The highest pressure on wild plant resources (but also on mushrooms and snails) is exerted in the counties of Transylvania, a region with a great diversity of habitats, among which semi-dry basiphilous grasslands are considered to have the highest floristic diversity $\left(79 \mathrm{sp} . / \mathrm{m}^{2}\right)$ for these types of grasslands in the entire world [15].

Romania has the most significant surface areas with quasi-virgin forests in Europe and also, many investors who wish to cultivate large surfaces with monocultures, to export a great number of live sheep and cattle or to sell large amount of wood from the Carpathian forests, as well as impressive quantities of wild berries, medicinal plants, mushrooms, snails, leeches, etc. However, the considerable benefits accrued reach only a small number of individuals, and the negative effects of this exploitation affect millions of local inhabitants. In the first place, these inhabitants are not happy and consequently, do not live in harmony with the environment: "When a man is happy he is in harmony with himself and his environment" [4, p. 60].

Our laws are harmonized with those of the EU, but their application is frequently influenced by various factors, among which the lack of professionalism of those with specific qualifications in this field, the investors' wish to gain big profits, the poor information and participation of the general public, etc., even a lack of common sense. For “... where there is common sense, laws are useless..., where common sense is missing, laws are helpless" [3, p. 17].

\section{Materials and Methods}

This study (the second of this type in the Romanian literature, after Mocanu, 1998-99) was performed based on the analysis of documents regarding the requests of commercial societies (S.C., including RNP -Romsilva) and physical persons (P.P.) whose sphere of activity also comprises this resource - medicinal plants; adequate evaluation (AE) studies conducted by accredited institutions; as well as scientific approvals issued by NMC (Nature Monuments Commission of the Romanian Academy).

For harvesting and commercializing resources from the spontaneous environment, Romanian legislation [7] also requires the scientific approval of NMC, which is based on an AE study that estimates the productive potential for each requested species in the county or area mentioned by the beneficiary and proposes the quantities allocated to the society concerned. Specific authorizations are issued, after obtaining this approval, by the competent authorities in this field, which can be depending on the case: County Environmental Protection Agencies, local Councils, forest districts, administrators and custodians of protected areas, or owners of forest land, orchards or plantations.

For the present case study, Mureş county (considering the anniversary symposium organized by the Faculty of Pharmacy in Târgu Mureş on 30 May - 1 June 2018) and the year 2017 were taken as an example, and an inventory of medicinal species from the spontaneous flora of this county, a comparative analysis of the requested quantities, proposed on the basis of $\mathrm{AE}$ and approved by NMC, was made separately for each type of drug used. Having a general picture of the situation in Romania, the strategies adopted by applicants in order to obtain the largest possible quantities allocated from these resources were also evidenced. 


\section{Results and Discussions}

\subsection{Strategies adopted by commercial societies}

The first strategy adopted by S.C. is the diversification of the requested plant resources: medicinal plants, berries, mushrooms, one of these categories being principal and the other secondary. Thus, in Romania, in 2017, 9 S.C.s requested only medicinal plants, 4 - mushrooms and medicinal plants, 43 - mushrooms, medicinal plants and berries, 2 - berries and medicinal plants, and 80 - mushrooms and berries. Frequently, harvesting of two and even three organs from the same species is requested in the same area.

For example, in 2017, S.C. "A" (from Reghin) requested in Mureş county $5 \mathrm{t}$ of flowers and $20 \mathrm{t}$ of fruit of Crataegus monogyna, $25 \mathrm{t}$ of flowers and $40 \mathrm{t}$ of fruit of Sambucus nigra, etc., and S.C. "B" (also from Reghin) requested in Mureş county $5 \mathrm{t}$ of flowers and $1.5 \mathrm{t}$ of rhizomes of Primula veris, $20 \mathrm{t}$ of leaves and $28 \mathrm{t}$ of fruit of Vaccinium myrtillus, etc.

A second strategy consists of requesting very large quantities, so that the approved quantities come close to the available capacities or the estimated gains. Frequently, these requested quantities are almost equal to or even higher than the potential estimated by the institutions responsible for adequate evaluation (Table 1). In addition, S.C.s very rarely request approval for one county; most of them request approvals for at least 5 counties (and some of them for more than 30 counties!), which favors achieving the proposed goal, including the acquisition of plant material from companies lacking the infrastructure required for the processing of these plants.

Table 1: An example of one of the strategies adopted by commercial societies (S.C. "X" from Tg. Mureş) in 2017: requesting quantities (in t) that can exceed the productive potential in the area intended for harvesting (*)

\begin{tabular}{l|c|c|c|c}
\hline \multicolumn{1}{c|}{ Species/drug } & P. & R. & AE & NMC \\
\hline Arnica montana - flores & 8 & $\mathbf{1 5} *$ & 2 & 2 \\
Juniperus communis - fructus & 80 & 20 & 15 & 10 \\
Primula veris - flores & 11 & 10 & 3 & 3 \\
Matricaria recutita - flores & 14 & 10 & 6 & 5 \\
Colchicum autumnale - semen & 8 & $\mathbf{1 0} *$ & 2.5 & 2 \\
Frangula alnus - cortex & 7.5 & $\mathbf{1 0} *$ & 2.5 & 2 \\
Helianthus tuberosus - radix & 8 & $\mathbf{1 0} *$ & 3 & 2 \\
\hline
\end{tabular}

Note: P. - potential estimated for the area mentioned by the S.C., R. - requested quantities, AE quantities proposed by the institution performing the adequate evaluation study, NMC quantities approved by NMC.

The principal activity of many S.C.s is exclusively medicinal plant export given the higher price they obtain (e.g. a society from Ibăneşti, Mureş county), while others are exclusively focused on harvesting these plants and selling them (certainly, at a negotiated price!) to companies that have processing equipment as well as permanently employed staff.

Finally, there are also cases in which approvals are requested by two or three S.C.s that belong in fact to the same shareholders. In this way, approvals for higher quantities are obtained and implicitly, the number of requesting societies increases, which has already been observed this year (2018), when their number has reached more than 100, compared to 75-80 in previous years. In the case of truffles (Tuber sp.), there have also been some requests from P.P.s who 
subsequently sell this delicacy to commercial societies, based in the residence locality of these persons.

In addition to the approved quantities, a great problem is related to the way harvesting is carried out, let alone the fact that, frequently, species close to those of interest are harvested, which are either endemic or of particular phytogeographical importance. For example, many S.C.s explicitly request Thymus serpyllum herb, a species that is reported as rare in our country [1] or its presence is questioned [12]. In fact, several species of thyme are harvested, such as Th. glabrescens agg. How many collectors will be able to differentiate the common thyme species from the endemites Th. comosus, Th. bihoriensis, Th. pulcherrimus or from the CarpathianBalkan species Th. dacicus, Th. praecox subsp. polytrichus, etc.?

All NMC approvals specify: "The recommendations mentioned in the study will be followed", and these adequate evaluation (AE) studies highlight forbidden harvesting practices and actions (e.g. cutting or breaking the branches of trees and shrubs, harvesting only part of the leaves or flowers of an individual, leaving some individuals to ensure regeneration, harvesting every two years from the same place, etc.), as well as the obligation of displaying the harvesting rules at the collection points.

What happens in reality? - in very many cases, the exact opposite of these interdictions or recommendations!

\subsection{Analysis of requests in 2017, in Mureş county}

In 2017, 33 S.C.s (based in 12 counties: AB-1, BH-4, BN-3, BZ-1, CJ-2, HD-2, HR-1, MS-10, SB-1, SJ-4, SM-2, SV-1, and Bucharest-1) and 11 P.P. (all in Mureş county) requested approvals for medicinal plant harvesting.

These requests involved 109 spontaneous medicinal plant species (Table 3) and 6 cultivated species (Morus alba - folium et radix, Aesculus hippocastanum - folium et semen, Castanea sativa - folium, Juglans regia - folium, Melissa officinalis - herba and Salvia officinalis - herba). However, the therapeutic potential of the spontaneous flora in Mureş county is much greater. Thus, in only the plains area of the county, Oroian [8] mentions 225 species, and in one Natura 2000 habitat (6520 - mountain hay meadows) in Gurghiu Mountains, Oroian et al. [10] report 89 such species.

The greatest number of requested spontaneous species refers to herba (47 spp.), followed, in approximately equal proportions, by folium (26 spp.), radix (21 spp.) and fructus (20 spp.). For 5 species, harvesting of 3 organs was requested (e.g. Crataegus monogyna: flowers, leaves and fruit, Corylus avellana: leaves, fruit and buds), and for 20 species, harvesting of 2 organs was requested (Table 3).

The requested quantities from the spontaneous flora totalled almost 7,706 $\mathbf{t}$ (of which only $8 \mathrm{t}$ requested by P.P.s), the institutions authorized to perform adequate evaluation (AE) studies proposed 4,529 t, and NMC approved only 3,926 t (Table 2). The largest quantities requested were those of fruit, followed by herb, leaves and flowers, but in some cases, the NMC's approval reduced thequantities by $30-60 \%$ because a number of aspects were considered. Thus, our decisions took into account the evaluations of the habilitated institutions regarding the potential of each region, the biology of each species, the organ/organs requested to be harvested, the animal species (vertebrates and invertebrates) that consume these plants, the role of these resources in the functioning of the ecosystems concerned, as well as the material and human 
resources available to these requesting bodies.

To these quantities, those regarding the "seeds, bulbs and rhizomes from various species with decorative value" (requested by a S.C. in Reghin) can be added, which include Cornus mas, Corylus avellana, Crataegus monogyna, Prunus spinosa, P. avium, Rubus fruticosus, Fragaria vesca, Sambucus nigra, Vaccinium myrtillus, Humulus lupulus, etc., species that have therapeutic properties as well.

It is not known exactly how much the qualified institutions authorized and especially, how much was harvested in reality, given that NMC does not have a control right, but the responsible authorities (namely the Environmental Guard, the Forest Guard and the National Statistics Institute) should inform the public.

Table 2: The quantities of medicinal plants (in $t)$ requested (R), proposed by the institutions authorized to perform adequate evaluation (AE) studies, and approved by NMC in 2017 in Mureş county

\begin{tabular}{l|c|c|c|c|c|c|c}
\hline & S.C. & & & P.P. & & & $\begin{array}{l}\text { Total } \\
\text { approved } \\
\text { by NMC }\end{array}$ \\
\hline Drug & R. & AE & NMC & R. & AE & NMC & \\
\hline Flores & 803.8 & 520.6 & 394.6 & 0.61 & 0.61 & 0.61 & $\mathbf{3 9 5 . 2 1}$ \\
Fructus & 4,722 & 2,351 & $1,981.7$ & 3.58 & 3.58 & 3.58 & $\mathbf{1 , 9 8 5 . 2 8}$ \\
Folium & 849.6 & 772 & 728 & 1.43 & 1.43 & 1.43 & $\mathbf{7 2 9 . 4 3}$ \\
Herba & 912 & 658.7 & 605.4 & 1.9 & 1.9 & 1.9 & $\mathbf{6 0 7 . 3}$ \\
Radix & 224.5 & 122.3 & 117.5 & 0.4 & 0.4 & 0.4 & $\mathbf{1 1 7 . 9}$ \\
Cortex & 75 & 18.3 & 16.5 & 0.04 & 0.04 & 0.04 & $\mathbf{1 6 . 5 4}$ \\
Gemae & 81 & 54 & 51 & - & - & - & $\mathbf{5 1}$ \\
Semen & 27 & 18.3 & 18.3 & - & - & & $\mathbf{1 8 . 3}$ \\
Variae & 11 & 5.5 & 5.5 & - & - & - & $\mathbf{5 . 5}$ \\
\hline TOTAL & $\mathbf{7 , 7 0 5 . 9}$ & $\mathbf{4 , 5 2 8 . 7}$ & $\mathbf{3 , 9 1 8 . 5}$ & $\mathbf{7 . 9 6}$ & $\mathbf{7 . 9 6}$ & $\mathbf{7 . 9 6}$ & $\mathbf{3 , 9 2 6 . 4 6}$ \\
\hline
\end{tabular}

Table 3: Medicinal plant species and organs requested to be harvested in 2017 in Mureş county $(\mathrm{Fl}=\mathrm{flores,}$ $\mathbf{F r t}=$ fructus, $\mathbf{F o}=$ folium, $\mathbf{H}=$ herba, $\mathbf{R d}=$ radix, $\mathbf{C o}=$ cortex, $\mathbf{G m}=$ gemae, $\mathbf{S e}=$ semen, $\mathbf{R s}=$ resina)

\begin{tabular}{|c|c|c|c|c|c|c|c|c|c|c|}
\hline $\begin{array}{l}\text { Crt. } \\
\text { No. }\end{array}$ & Species & Fl. & Frt. & Fo. & H. & Rd. & Co. & Gm & Se. & Rs. \\
\hline 1 & Abies alba & & & & & & & & & $\mathrm{x}$ \\
\hline 2 & Achillea millefolium & & & & $\mathrm{x}$ & & & & & \\
\hline 3 & Acorus calamus & & & & & $\mathrm{X}$ & & & & \\
\hline 4 & Agrimonia eupatoria & & & & $\mathrm{x}$ & & & & & \\
\hline 5 & Agropyron repens & & & & & $\mathrm{x}$ & & & & \\
\hline 6 & Alchemilla vulgaris & & & $\mathrm{X}$ & $\mathrm{x}$ & & & & & \\
\hline 7 & Allium ursinum & & & $\mathrm{x}$ & $\mathrm{x}$ & & & & & \\
\hline 8 & Althaea officinalis & & & $\mathrm{x}$ & & $\mathrm{x}$ & & & & \\
\hline 9 & Arctium lappa & & & & & $\mathrm{x}$ & & & & \\
\hline 10 & Armoracia rusticana & & & & & $\mathrm{x}$ & & & & \\
\hline 11 & Arnica montana & $\mathrm{x}$ & & & & & & & & \\
\hline 12 & Betonica officinalis & & & & $\mathrm{x}$ & & & & & \\
\hline 13 & Betula pendula & & & $\mathrm{x}$ & & & & $\mathrm{x}$ & & \\
\hline 14 & Capsella bursa-pastoris & & & & $\mathrm{x}$ & & & & & \\
\hline 15 & Centaurea cyanus & $\mathrm{x}$ & & & $\mathrm{x}$ & & & & & \\
\hline 16 & Centaurium umbellatum & & & & $\mathrm{x}$ & & & & & \\
\hline 17 & Chelidonium majus & & & & $\mathrm{x}$ & & & & & \\
\hline 18 & Cichorium intybus & & & & $\mathrm{x}$ & $\mathrm{x}$ & & & & \\
\hline
\end{tabular}




\begin{tabular}{|c|c|c|c|c|c|c|c|c|c|c|}
\hline 19 & Colchicum autumnale & & & & & & & & $\mathrm{x}$ & \\
\hline 20 & Convallaria majalis & & & $\mathrm{x}$ & & & & & & \\
\hline 21 & Convolvulus arvensis & & & & $\mathrm{x}$ & & & & & \\
\hline 22 & Cornus mas & & $\mathrm{x}$ & & & & & & & \\
\hline 23 & Corylus avellana & & $\mathrm{x}$ & $\mathrm{x}$ & & & & $\mathrm{x}$ & & \\
\hline 24 & Crataegus monogyna & $\mathrm{x}$ & $\mathrm{x}$ & $\mathrm{x}$ & & & & & & \\
\hline 25 & Dryopteris filix-mas & & & & & $\mathrm{x}$ & & & & \\
\hline 26 & Epilobium parviflorum & & & & $\mathrm{x}$ & & & & & \\
\hline 27 & Equisetum arvense & & & & $\mathrm{x}$ & & & & & \\
\hline 28 & Eryngium planum & & & & $\mathrm{x}$ & & & & & \\
\hline 29 & Fagus sylvatica & & & & & & & $\mathrm{x}$ & & \\
\hline 30 & Filipendula ulmaria & & & & $\mathrm{x}$ & & & & & \\
\hline 31 & Fragaria vesca & & $\mathrm{x}$ & $\mathrm{x}$ & & & & & & \\
\hline 32 & Frangula alnus & & & & & & $\mathrm{X}$ & & & \\
\hline 33 & Fraxinus excelsior & & & $\mathrm{x}$ & & & & & & \\
\hline 34 & Galium aparine & & & & $\mathrm{X}$ & & & & & \\
\hline 35 & Galium odoratum & & & & $\mathrm{x}$ & & & & & \\
\hline 36 & Galium verum & & & & $\mathrm{x}$ & & & & & \\
\hline 37 & Gentiana asclepiadea & & & & & $\mathrm{x}$ & & & & \\
\hline 38 & Geum urbanum & & & & $\mathrm{x}$ & $\mathrm{x}$ & & & & \\
\hline 39 & Glechoma hederacea & & & & $\mathrm{x}$ & & & & & \\
\hline 40 & Glycyrrhiza glabra & & & & & $\mathrm{x}$ & & & & \\
\hline 41 & Helianthus tuberosus & & & & & $\mathrm{x}$ & & & & \\
\hline 42 & Heracleum sphondylium & & & & $\mathrm{x}$ & & & & & \\
\hline 43 & Hippophae rhamnoides & & $\mathrm{x}$ & $\mathrm{x}$ & & & & & & \\
\hline 44 & Humulus lupulus & $\mathrm{x}$ & & & & & & & & \\
\hline 45 & Hypericum perforatum & & & & $\mathrm{x}$ & & & & & \\
\hline 46 & Inula helenium & & & & & $\mathrm{x}$ & & & & \\
\hline 47 & Juniperus communis & & $\mathrm{x}$ & & & & & & & \\
\hline 48 & Lamium album & & & & $\mathrm{x}$ & & & & & \\
\hline 49 & Leonurus cardiaca & & & & $\mathrm{x}$ & & & & & \\
\hline 50 & Lycopodium clavatum & & & & $\mathrm{x}$ & & & & & \\
\hline 51 & Malus sylvestris & & $\mathrm{x}$ & & & & & & & \\
\hline 52 & Malva sylvestris & & & $\mathrm{x}$ & & & & & & \\
\hline 53 & Matricaria recutita & $\mathrm{x}$ & & & & & & & & \\
\hline 54 & Melilotus officinalis & & & & $\mathrm{x}$ & & & & & \\
\hline 55 & Mentha aquatica & & & & $\mathrm{x}$ & & & & & \\
\hline 56 & Mentha arvensis & & & & $\mathrm{x}$ & & & & & \\
\hline 57 & Mentha pulegium & & & & $\mathrm{x}$ & & & & & \\
\hline 58 & Mycelis muralis & & & & $\mathrm{x}$ & & & & & \\
\hline 59 & Ononis spinosa & & & & & $\mathrm{x}$ & & & & \\
\hline 60 & Origanum vulgare & & & & $\mathrm{x}$ & & & & & \\
\hline 61 & Padus avium & & $\mathrm{x}$ & & & & & & & \\
\hline 62 & Petasites hybridus & & & $\mathrm{x}$ & & $\mathrm{x}$ & & & & \\
\hline 63 & Picea abies & & & & & & & $\mathrm{x}$ & $\mathrm{x}$ & $\mathrm{x}$ \\
\hline 64 & Pinus sylvestris & & & & & & & $\mathrm{x}$ & & \\
\hline 65 & Plantago lanceolata & & & $\mathrm{x}$ & & & & & & \\
\hline 66 & Plantago major & & & $\mathrm{x}$ & & & & & & \\
\hline 67 & Polygonum aviculare & & & & $\mathrm{x}$ & & & & & \\
\hline 68 & Populus nigra & & & & & & & $\mathrm{x}$ & & \\
\hline 69 & Potentilla anserina & & & & $\mathrm{x}$ & & & & & \\
\hline 70 & Primula veris & $\mathrm{x}$ & & & & $\mathrm{x}$ & & & & \\
\hline 71 & Prunus avium & & $\mathrm{x}$ & & & & & & & \\
\hline 72 & Prunus spinosa & $\mathrm{x}$ & $\mathrm{x}$ & & & & & & & \\
\hline 73 & Pulmonaria officinalis & & & & $\mathrm{x}$ & & & & & \\
\hline
\end{tabular}




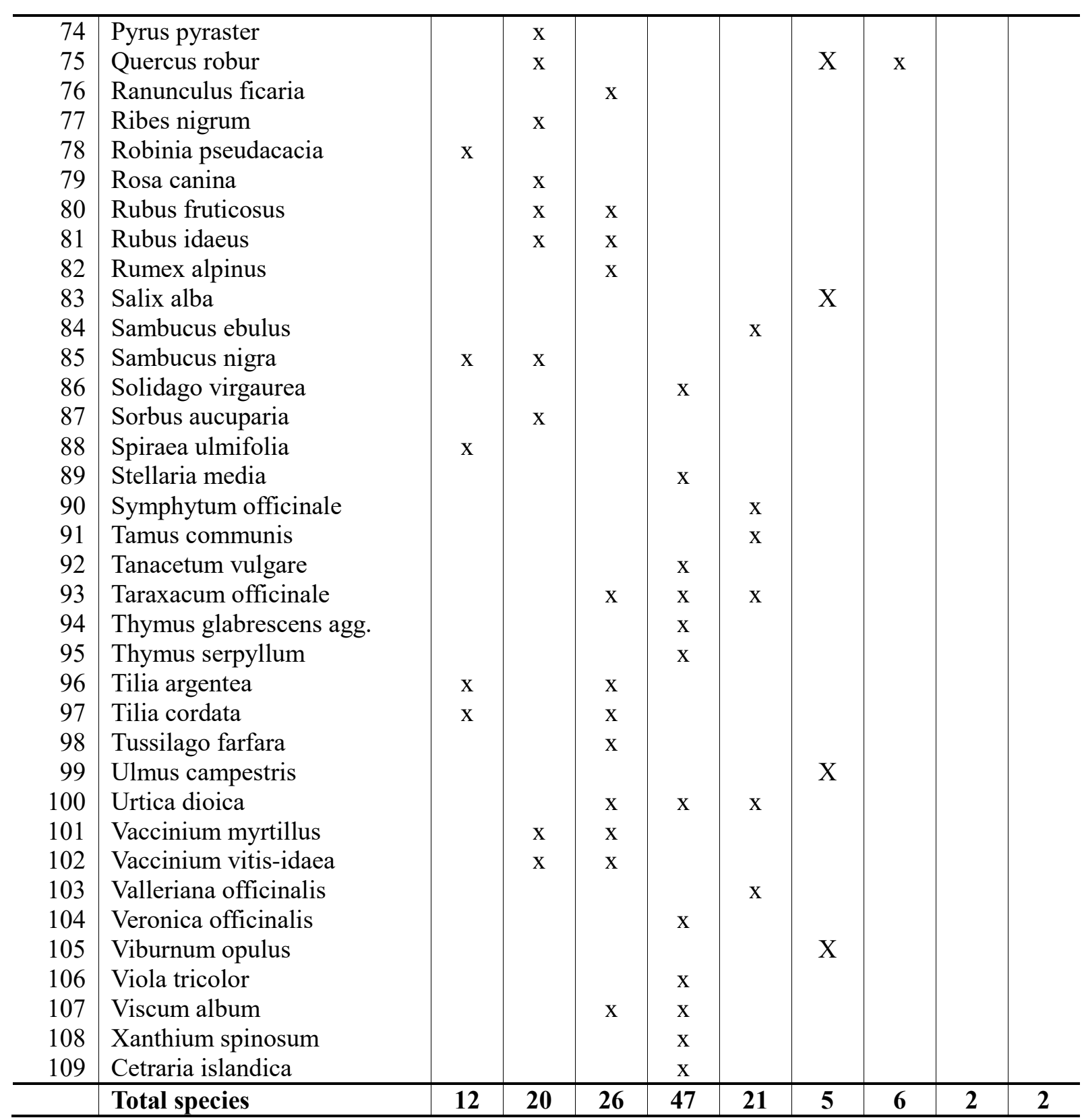

\section{Conclusions}

1. Even if in Mureş county the pressure on these resources does not reach the level of other counties in Transylvania, we believe that our analysis has provided evidenced of the need for all organizations with responsibilities in the field of environmental conservation and protection to advocate a truly sustainable use of this important resource (uti sed non abuti!), which is subjected to many additional pressures. A recent honorary member of the Romanian Academy - Pope Francis, said: "We are stewards not owners of Creation ..." [14, p. 62], and subsequently urged “... to protect, care for, sustain and develop Creation" [idem, p.63].

2. All strategies for the conservation of biodiversity should take into account the biology, the role and position in the trophic chains and networks of the species intended to be used economically, as well as the traditions of local communities related to the use of this resource. Based on "best practices" in some EU countries, we consider the elaboration of a Guide to the 
management of Romanian natural resources necessary, as a useful tool for both economic agents and institutions responsible for managing these resources.

3. Precisely because "Life in the countryside, with farm household products, does not meet the current needs of the population" [11, p. 12] we are obliged, beyond our purely scientific interests, to contribute, through dialogue and discussions with the general public, to finding that judicious principle of man's coexistence with nature, about which French ornithologist Jean Dorst spoke more than half a century ago.

4. "Nature conservation will become effective and real only when it is an integral part of the philosophy and behavior of all" (Declaration of the United Nations Conference on the Human Environment, Stockholm, June 1972). This process is and will be an extremely difficult one, particularly in the "market economy" where, as famous J.Y. Cousteau emphasized, paraphrasing Oscar Wilde: "Nowadays people know the price of everything and the value of nothing", "The market system, as we are living it today, is doing more damage to the planet than anything else because everything has a price but nothing has value" [ap. 3, p. 152].

Finally, even the definition of pharmaceutical botany (considered "... an applied discipline whose main object is the morphological, anatomical and taxonomic study of medicinal plants", [9, p. 22]) will have to be complemented by the environmental protection aspect (mainly focusing on "in situ" conservation), required for the survival of this discipline, so that the potential offered by our medicinal plants can be extensively known and especially used with maximum efficiency.

\section{REFERENCES}

1. Ciocârlan ,V., 2009, Flora ilustrată a României. Pteridophyta et Spermatophyta, Ed. Ceres, București.

2. Coste I., 1982, Omul, Biosfera şi Resursele naturale. Introducere în Ecologia resurselor natural, Ed. Facla, Timişoara.

3. Dărămuş, N.R., 2005, Dregătoria cârtiţelor, Ed. Eco-Logic, Gura Humorului

4. xxx, 2007, Epigrams of Oscar Wilde, Wordsworth Editions Limited, Ware, UK.

5. Mocanu, P., 1998-1999, Situaţia speciilor de interes medicinal din flora spontană. Măsuri pentru protecţia, conservarea şi utilizarea lor durabilă, Ocrot. nat. med. înconj., 42-43: 87-89.

6. Muntean, L.S.-coord., 2007, Tratat de plante medicinale cultivate şi spontane, Ed. Risoprint, ClujNapoca.

7. xxx, 2008, Ordin nr. 410 pentru aprobarea Procedurii de autorizare a activităţilor de recoltare, capturare şi/sau achiziţie şi/sau comercializare pe teritoriul naţional sau la export. Min. Mediului şi Dezvoltării Durabile, Monitorul Oficial, nr. 339/1 mai 2008.

8. Oroian, S., 2000, Conspectul plantelor medicinale spontane din zona de câmpie a judeţului Mureş, Marisia - Studii şi materiale, Tg. Mureş, 26: 15-25

9. Oroian, S., 2011, Botanică farmaceutică, Ed. University Press, Târgu Mureş.

10. Oroian, S., Sămărghiţan, M., Hiriţiu, M., Coşarcă, S., Tănase, C., 2016, The diversity of medicinal and aromatic plants encountered in Natura 20006520 habitat from Gurghiu Mountains, J. Plant Develop., 23: 179-186.

11. Rakosy, L., Crişan, A., Craioveanu, C., 2018, Beneficiile naturii în situl Natura 2000 "Dealurile Clujului de Est". The Benefits of Nature in the Natura 2000 Site "Eastern Cluj Hills", Pensoft, s.ed.

12. Sârbu, I., Ștefan, N., Oprea, A., 2013, Plante vasculare din România. Determinator ilustrat de teren, Ed. VictorBVictor, București. 
13. Simionescu, B.-coord., 2015, Resursele naturale rezerve strategice, ce folosim şi ce lăsăm generaţiilor viitoare. In: Vlad I-V.-coord., 2015, Strategia de dezvoltare a României în următorii 20 de ani, Ed. Acad. Rom., vol.I: 37-94.

14. Tornelli, A., Agasso, D.jr., 2017, Sfaturi prietenești de la Papa Francisc: cuvinte care ne ajută să trăim mai bine, Ed. Viața Creștină, Cluj-Napoca. Trad. Laszlo A.

15. Wilson, J.B., Peet, R.K., Dengler, J., Pärtel, M., 2012, Plant species richness: the world records, Journal of Vegetation Science, 23: 796-802.

\section{PLANTELE MEDICINALE SPONTANE: UTI SED NON ABUTI!. STUDIU DE CAZ: JUDEȚUL MUREŞ}

\section{(Rezumat)}

Dincolo de defrişările masive (şi, deseori, ilegale), în România constatăm o creştere puternică a presiunii asupra resurselor biologice, paralel cu ignorarea regulilor de colectare/recoltare a acestora. Dispunând de materialele care au stat la baza avizelor ştiinţifice, în numele CMN dorim să tragem un semnal de alarmă şi să îndemnăm la cumpătare şi raţiune în exploatarea acestor resurse.

Presiunea cea mai puternică se exercită în județele din Transilvania, motiv pentru care s-a ales jud. Mureş (cu o presiune moderată între judeţele transilvane), analizând situaţia plantelor medicinale şi anul 2017.

Pentru a obţine avizele ştiinţifice şi apoi autorizaţiile, societăţile comerciale adoptă multiple strategii, în special solicitând cantităţi mari (v. tab. 1) din mai multe judeţe şi diversificând categoriile de resurse (plante medicinale şi fructe de pădure, plante medicinale şi ciuperci, fructe de pădure şi ciuperci etc.).

În 2017, din jud. Mureş s-au vizat 109 sp. de plante medicinale spontane (v. tab. 3) şi 6 sp. cultivate, cererile totalizând 7.706 t. Solicitările au fost din partea a 33 societăţi comerciale (din care doar 10 cu sediul în jud. Mureş) şi a 11 persoane fizice autorizate din acest județ. Studiile de evaluare adecvată au propus $4.529 \mathrm{t}$, iar CMN a avizat doar 3.926 t (v. tab. 2), diminuând cantităţile la acele specii de la care se folosesc părţile subterane, la cele la care se recoltează şi frunzele şi florile şi fructele, la cele cu rol cheie în funcţionarea ecosistemelor, precum şi la cele cu regenerare mai înceată.

Cât s-a recoltat şi cât s-a recoltat ilegal? răspunsul se află (sau ar trebui să se afle) la organismele care au responsabilităţi de control în domeniul mediului.

Datoria noastră, a tuturor cetăţenilor acestei ţări, este să milităm pentru o utilizare raţională şi, mai ales, pentru o valorificare eficientă a acestor resurse, nu ca materie primă, ci ca şi produs finit! 